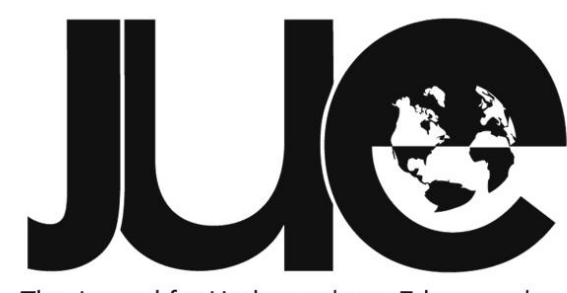

The Journal for Undergraduate Ethnography

\title{
Building a Life Despite It All: Structural Oppression and Resilience of Undocumented Latina Migrants in Central Florida
}

\section{Sarajane Renfroe}

\author{
Rollins College, srenfroe@rollins.edu
}

\section{ABSTRACT}

Immigrants to the United States encounter a multitude of challenges upon arriving. This is further complicated if migrants arrive without legal status and even more so if these migrants are women. My research engages with Kimberlé Crenshaw's concept of intersectionality to examine interlocking systems of oppression faced by undocumented migrant women living in Central Florida. I worked mainly in Apopka, Florida, with women who migrated from Mexico, Central America, and South America. I found that three broad identity factors shaped their experiences of life in the U.S.: gender, undocumented status, and Latinx identity. The last factor specifically affected women's lives through not only their own assertions of their identity, but also outsider projections of interviewees' race, ethnicity, and culture. My research examines how these identity factors affected my interviewees and limited their access to employment, healthcare, and education. Through a collaborative research project involving work with Central Floridian non-profit and activist organizations, I conducted interviews and participant observation to answer my research questions. Through my research, I found that undocumented Latina migrants in Central Florida face structural vulnerabilities due to gendered and racist immigration policies and social systems, the oppressive effects of which were only partly mitigated by women's involvement with community organizations. My research exposes fundamental and systemic failures within U.S. immigration policies and demonstrates that U.S. immigration policy must change to address intersectional oppression faced by undocumented Latina migrants.

Keywords: immigration, intersectionality, immigration policy, gender, Latinx identity 
t's a sunny day - normal for Florida in the summertime - and I'm standing next to Jasmine's car as she knocks on the door of a mobile home. Jasmine is an AmeriCorps member working with Hope CommUnity Center, a local organization working to support the immigrant community in Central Florida. Jasmine introduces me to the woman who emerges from the doorway of the mobile home wearing a calf-length cotton dress and a headscarf. Her name is Tatiana, and she talks with Jasmine for a moment before they beckon me toward them. We walk into her home, and I am greeted by three young children playing with a large plastic dollhouse. I perch myself on a sofa and Tatiana begins her story. She is one of eight migrant women I interviewed during the summer of 2017, with fellow researcher Rachel Newcomb as part of a collaborative student-faculty research program through Rollins College. Our research was motivated by the following question: how do women experience migration differently from men? During our interviews, we found that women attested to a very different experience of migration from their male family members and friends. Rachel and I discovered that women's experiences were not only shaped by gender, but also by an undocumented status and Latinx identity. These were essential factors in systems of oppression faced by our interviewees, and because of this finding, I chose to focus my own analysis on the intersectionality of these identity factors and their relationship to oppression faced by interviewees. In following the work of previous researchers (Kynsilehto 2011; Cherubini 2011), I utilize the framework of intersectionality as a fundamental theoretical perspective of this article in order to analyze women's experiences of migration. I describe in detail how and why my interviewees' experiences are unique through using the intersectionality framework, and then I describe the consequences of this by analyzing my interviewees' relationship to employment, healthcare, and education. For these women, the migration experience is structurally oppressive, yet despite these significant barriers, I also found that my interviewees showed agency and subverted their oppression by building lives in the United States.

\section{Methodology}

My research examines the multi-dimensional and complex nature of human migration from Mexico, Central America, and South America to the United States. I examine the ways in which gender, Latinx identity, and an undocumented status intersectionally affect the lives of undocumented Latina migrants in Central Florida. I employ a multidisciplinary approach toward understanding gender and migration, drawing from cultural anthropology, medical anthropology, sociology, and geography. To accomplish this study, I used participant observation and formal and informal interviews to seek answers to both of my research questions: (1) How is the migration experience gendered, and (2) What are the consequences of a gendered migration process? I conducted eight interviews averaging approximately one hour each with undocumented Latina migrants living in Central Florida. My research is further informed by approximately 300 hours of participant observation, conducted intermittently over the span of four years. Participant observation included volunteering with a migrants' rights advocacy organization (14 hours), tutoring at Hope CommUnity Center (74 hours), interning with Mi Familia Vota (100 hours), participating in three weekend-long immersions at Hope CommUnity Center (108 hours), and attending a citizenship workshop at Hope CommUnity Center (4 hours).

Much of my applied research occurred when I worked directly with anthropologist Rachel Newcomb through Rollins College's studentfaculty collaborative research program during the summer of 2017. We conducted a comparative study examining how migrant women experience life in their receiving countries; as our countries of comparison, we chose the United States and Spain. We worked specifically with Latina immigrants in the 
greater Orlando area of Florida, and with Moroccan migrant women in Barcelona, Spain. This collaborative research informs this article which focuses on the research in Florida.

\section{Theoretical Background: Intersectionality}

Kimberlé Crenshaw developed her theory of intersectionality to address the multidimensionality of structural violence faced by women. Her framework provides a basis upon which to analyze how the combination of certain identity factors increases the vulnerability of certain demographics to oppression in the United States. My research applies Crenshaw's theory of intersectionality to the experiences of women migrants now living in Central Florida who came to the United States from Mexico, Central America, and South America and are undocumented, meaning that they do not have documents stating their legal residency in the United States. Through interviews and participant observation, I found that the lives of the Latina migrant women living in Central Florida were fundamentally shaped by the consequences of the intersections of gender, Latinx identity, and their undocumented status. In addition, I also discovered that Latina migrants in the U.S. found ways around the oppressive structures in their lives by fulfilling their needs in unique ways. Despite the immense barriers faced by my research participants every day, each woman described her own form of resistance through the simple act of building a life in the United States. In this article, I assert that these barriers are the product of American policy that prevents undocumented Latina migrants from legalizing their status, which effectively limits women's access to safe and fair employment, education, and affordable healthcare. Through my analysis, I will not only describe how these systems of oppression relate to the intersectionality of these women's identities, but also how women resist the oppressive consequences of this intersection. Crenshaw writes that identity politics and the cultural use of identity factors, which have historically caused marginalization, "need not be the power of domination; it can instead be the source of political empowerment and social reconstruction" (Crenshaw 1991). Through utilizing intersectionality as my research framework, I examine the multiple "contextual dynamics of power" (Cho, Crenshaw, and McCall 2013) at play in the lives of my interviewees. My research demonstrates both the continuing marginalization faced by undocumented Latina migrants in Central Florida due to their lack of formal documentation demonstrating their right to live in the United States. That said, my research also emphasizes the strength and resiliency of these same women as they navigate structural barriers and find ways to create lives in the United States.

\section{Latinx Identity}

My project specifically engaged with women who migrated from Mexico, Central America, and South America. Latinx identity shaped interviewees' experiences in multiple ways. During our interviews, women described interactions with people, institutions, and organizations that were shaped by a recognition or projection of their race, nationality, culture, and/or ethnicity. These identity categories are broad and do not sufficiently describe or include what it means to be Latinx, and thus my descriptions of this identity factor are inherently limited. My discussion of Latinx identity implicates an outsider projection of this identity more than it describes my interviewees' self-described identities. It is important to discuss this factor, though, because it is exactly this projection and generalization of "Latinness" that my interviewees' experiences had in common. Furthermore, being from Mexico, Central America or South America placed my interviewees under specific immigration policy regimes. These laws not only determine immigration along lines of nationality, but also have racial dimensions (Armenta 2017, 16; Willen 2007, 338).

\section{Migration Status}

I assert that undocumented immigrants in the United States are treated as subhuman and barred from their basic human rights in the United States. Undocumented immigrants have highly limited access to American society and social institutions like education, jobs, and healthcare. Furthermore, because it is illegal to live in the U.S. without proper documentation, these migrants are subject to deportation at 
any time. Two specific pieces of legislation have focused on increasing the deportability of undocumented immigrants in the U.S.: the Secure Communities Program, and section 287 (g) of the Immigration and Nationality Act of 1996 (Kline 2017). These laws increased the power of local police to act as Immigration and Customs Enforcement (ICE) agents. This means that any police officer who finds an undocumented immigrant may arrest and detain them until a true ICE agent arrives and the migrant can be deported. This specifically affects Latinx migrants in the U.S. because it is more difficult for Latinx immigrants to be granted visas, refugee status, or citizenship, with the result that many slip into undocumented status (Zavella 2016, 36; De León 2015). Race and racism are heavily implicated in "legality" in the United States, and thus deportability (García 2017). Because Latinx immigrants in the U.S. are less likely to access documented status and due to the discretionary powers of police officers to engage individuals and the implications of racial profiling on officers' choices, Latinx migrants are more subject to deportation and racism in immigration policies. Effectively, Latinx migrants are ultimately unable to escape the danger and trauma of the U.S. southern border (Kline 2017, 397; Coleman 2007; Silvey 2007, 76). This border also represents a boundary between American society and outside states, and thus its metaphorical extension into the daily lives of immigrants represents their exclusion from American society even though they have already crossed the state boundary (Silvey 2007, 76).

Consequently, Latinx individuals in the U.S. are viewed as outsiders and non-American (Kline 2017, 339), which contributes to the process of constructing "deservingness" or "non -deservingness" for Latinx immigrants. This process occurs simultaneously with the construction of "policy narratives" that act upon American societal hegemony and thus shape the way the average American views Latinx immigrants (Fernandez 2013, 108). "Legality" and "illegality" in conversations about migration thus contain hidden meanings, with illegality (in reference to undocumented status) connoting a lack of deservingness (Willen 2011, 338; Salcido and Menjívar 2013, 347). A major consequence of asserting that Latinx immigrants are undeserving of access to American society and social institutions is the dehumanization of Latinx immigrants in the United States. This allows for such human rights abuses as racial profiling of Latinx individuals and undue detainment, arresting Latinx individuals as "collateral" during ICE raids of factories and businesses, and society-wide discrimination (Lopez et al. 2016, 2; Kline 2017, 399). The consequence of being undocumented as well as Latinx is to be determined as undeserving of basic human rights in the United States, and thus subhuman.

\section{Gender}

According to sociologist Pierrette HondagneuSotelo, "women and men do not enter the migration process equally" (1992, 394). The cause of this inequality is patriarchal structures in society and policy. Regardless of their origin, migrant women entering the United States encounter patriarchy in society. Gendered structures shape women's experiences before migration and during the decision-to-migrate process, and also in their lives in the United States. A review of literature describing "Latin American" patriarchy and gender structures reveals a highly generalized assertion that women are perceived as family caregivers, which relegates Latina women to a passive role in society as "recipients of state policy" and not as "agents, claims-makers or active citizens" (Goldring 2001, 504, 519). Such literature paints all Latina women as passive outside of domestic life, lacking the power to decide whether to migrate, when, to where, and every other aspect of the decision-making processes regarding migration (HondagneuSotelo 1992, 394-395, 399). Migrant women from these countries are also assumed to be embedded in the "global care chain," in which childcare and domestic work are pull factors and common employment sectors for women from the Global South (Herrera 2013, 478). According to these theories of Latina women's limitation to the domestic sphere at every point in the migration process, authors assert that such women are stuck in a cycle of globally perpetuating gender norms (Herrera 2013, 478). This literature inevitably characterizes migrant women from Mexico, Central and South America as vulnerable and powerless. 
Although this generalization is problematic, it is true that there are gendered power structures that migrant women face throughout the process of migrating. Anthropologist Maria Olivia Salcido and sociologist Cecilia Menjívar $(2013,336)$ assert that "gender hierarchies are embedded in the formulation, interpretation, and implementation of immigration laws, as experienced by immigrants". Not only is it more difficult for women to go from being undocumented to documented (Salcido and Menjívar 2013, 349), but undocumented women face more barriers than undocumented men in accessing employment, healthcare, and education in the United States (Salcido and Menjívar 2013, 339). Furthermore, undocumented migrant women statistically experience higher negative health impacts than male migrants related to stress (Seelye 2017; Novak, Geronimus, and Martinez-Cardoso 2017; Lopez et al. 2017, 4; Neuman et al. 2010). This issue is further complicated by the fact that undocumented migrants are barred from accessing health insurance (through the Affordable Care Act of 2010). Through just this example of health, it is quickly evident how gender, Latinx identity, and migration status are interrelated and have multi-dimensional consequences for undocumented Latina women in the United States. Because of this, I find that the paradigm of intersectionality is most useful to examine the structural forces shaping the lives of undocumented Latina migrant women living in the United States.

\section{Analyses of Women's Experiences}

\section{Employment}

Throughout my interviews, women consistently expressed to me that they faced immense limitations to the types of employment available to them in the United States. Because of their undocumented status, women were unable to obtain jobs which required a social security number during the application process. Thus, the types of work available to them were generally informal and often exploitative. Employers sometimes withheld paychecks, pushed women to work beyond normal hours, or failed to warn of the dangers of direct contact with agricultural chemicals. Women attributed the exploitation they experienced not only to their undocumented status but also to racist assertions about their worth as workers. Furthermore, the types of work available to migrant women in Central Florida were highly gendered, and some interviewees experienced sexual violence in their work spaces. One woman, Isabella, explained to me that it has been much easier for men she knows to find work and that these men often receive higher wages for the same job as women. Thus, the forces limiting these women's access to employment are consequences of an intersectionality of gender, migration status, and perceived Latinx identity. In order to demonstrate the breadth of the effects of this intersectionality, I will first describe the jobs held by women I interviewed, then explain why they were limited to these jobs, and finally describe the effects of working these types of jobs.

Of the women I interviewed, many worked in their sending country as well as in the United States. Although sometimes the types of work they engaged in were similar in both places, often women had more opportunities for diverse types of employment in their origin countries. This fact stands in contrast to the general belief that migrants are always stuck in a cycle of the globalization of care work (Herrera 2013, 478). Rather, the women were more likely to end up in paid or unpaid care work in the U.S., despite their hopes for better jobs there. To describe how this process works, I include a table demonstrating the work women did before migrating to the U.S. and their employment within the U.S. (see Table 1).

This table demonstrates how Latina migrant women in Central Florida are predominantly limited to domestic work, agricultural work, and employment in the service industry. All of these types of work provide very little pay and are often informal. My interviewees explained that they were limited to these jobs because of their gender and also because they were undocumented. Two exceptions to this are Yelena and Isabella, whose stories represent how difficult it was for them to escape the limitations of employment in the United States. In order to best explain these processes, I will first tell Celia and Laura's stories to explain the effects of intersectional oppression for Latina migrants in the United States. I will then share 
Table 1

\begin{tabular}{|c|c|c|c|}
\hline Name & Sending country & Work in sending country & Work in the United States (chronologically) \\
\hline Isabella & Mexico & Farm labor & $\begin{array}{ll}\text { - } & \text { Door factory } \\
\text { - } & \text { Plant nursery } \\
\text { - } & \text { Trash/recycling company } \\
\text { - } & \text { Cleaning hotels } \\
\text { - } & \text { Mixing chemicals for a plant nursery } \\
\text { - } & \text { Currently: Receptionist at a non-profit } \\
& \text { organization in Central Florida }\end{array}$ \\
\hline Celia & Guatemala & $\begin{array}{l}\text { Picking tobacco and } \\
\text { peanuts }\end{array}$ & $\begin{array}{l}\text { - Cleaning dishes during the day, cleaning } \\
\text { offices at night } \\
\text { - Waitressing at a Mexican restaurant } \\
\text { - Currently: Domestic work (unpaid) }\end{array}$ \\
\hline Tatiana & Mexico & Unknown & $\begin{array}{l}\text { - Factory work } \\
\text { - Currently: Domestic work (unpaid) }\end{array}$ \\
\hline Rosalita & Mexico & Unknown & $\begin{array}{l}\text { - } \quad \text { Fruit packing } \\
\text { - } \quad \text { Currently: Domestic work (unpaid) }\end{array}$ \\
\hline Elisa & Mexico & Unknown & $\begin{array}{l}\text { - } \text { Farm work } \\
\text { - Landscaping } \\
\text { - Currently: Cleaning houses (paid in cash) }\end{array}$ \\
\hline Yelena & Panama & (Too young) & $\begin{array}{l}\text { - Work at a fast food chain restaurant } \\
\text { - Nursing }\end{array}$ \\
\hline Laura & Mexico & $\begin{array}{l}\text { Nanny } \\
\text { Cleaning offices } \\
\text { Accountant assistant }\end{array}$ & $\begin{array}{l}\text { - Cleaning houses } \\
\text { - Waitressing at a Mexican restaurant } \\
\text { - Currently: Domestic work (unpaid) }\end{array}$ \\
\hline Patricia & Mexico & Cleaning houses & - Currently: Domestic labor (unpaid) \\
\hline
\end{tabular}

the stories of Isabella and Yelena to demonstrate how they escaped the limitations of work generally available to undocumented Latina migrants in the United States. After these stories I will analyze the forces which shaped these women's experiences with employment, and how Isabella and Yelena were able to find better work.

\section{Celia's story}

Celia came from an impoverished family in the countryside of Guatemala, where she worked all day picking tobacco and peanuts with her family. Her father migrated to the U.S. first to attempt to make more money and send it back to her family, yet his remittances were not sufficient for her family's needs. Her uncle decided that the oldest children must also migrate to work in the U.S. for the survival of her family, so she and her older brother traveled with a chain of coyotes with her uncle. Coyotes are individuals who facilitate migrants' transportation across the U.S.-Mexico border. Often, coyotes charge a large fee for their services, even though the transportation they provide is generally unsafe and difficult for migrants. This experience was extremely difficult for Celia, because she was unable to get sleep during the three days they traveled atop a 
train from Mexico to the United States, nor could she eat because there was no food available for travelers such as herself.

After this traumatic experience, Celia found herself in California, where she worked cleaning dishes during the day and cleaning offices and schools at night. She lived with her uncle, who was very strict about what Celia wore and did she had to go to church with him and wear only dresses. He also insisted on listening in on all of her phone calls. Celia realized she needed to leave this man, so she soon left to live with her other uncle living in the United States. This uncle, though, was a drunkard and held parties at his house often, despite the fact that her sleeping space was the couch in the main room. She felt that he was "selling" her to men he invited to these parties because she "owed" him for living in his house, and he pushed her to socialize with his friends during the parties. Celia left this situation to return to the first uncle, but when she did, the second uncle threw her belongings away, including all of her documents from Guatemala and the expensive false passport she had purchased. During this entire experience, she was still working two jobs and not sleeping because she worked one at night and the other during the day.

Her only recourse was to contact her father, who found a service which would drive her across the country from California to Florida. The service cost her approximately $\$ 2,000$. When she had finally saved up the money, she traveled to Florida and moved in with her father and seven other men living in a small mobile home.

Celia immediately became responsible for cooking for the men because she was the only woman. They developed a system where the men bought groceries, and Celia cooked dinner each day. She was unemployed during this time, not for lack of trying to find a job but because she could not seem to get hired. Out of boredom, she accompanied the men to their roofing job each day. As time went by, Celia became known to her community as a skilled cook, which finally led to her finding work at a Mexican restaurant. She liked this job and met her husband there around a year after she began working. After marrying, despite her enjoyment of her work, her husband forced
Celia to leave the restaurant because he was jealous of her interactions with other men.

When I met her, Celia explained that her current work was cooking, cleaning, and taking care of her daughter Raquel. The only diversion from this daily routine was when she sometimes brought her daughter to Orlando City soccer games and to Disney World, but she remarked that she felt bored because these are the only activities her husband allowed her to do. She felt lonely because she did not know many other women in her community, but when she could, she went to Hope CommUnity Center to meet other Latina migrants.

\section{Laura's story}

Laura migrated from Mexico to California, and although she travelled with two of her siblings, most of her family stayed in Mexico. As a 15year-old girl in Mexico, she began working as a nanny, and when she was 17 she started cleaning as well. While she was working, she studied at a technical school for accounting and was able to get a job as an assistant accountant. As a young adult, she applied for a visa to work in the U.S. but was denied because she could not demonstrate enough proof of wealth. Laura decided to cross the border regardless, with the goal of working for just one year in the U.S. and then returning with savings to her family in Mexico. Yet when she arrived in California, she had an enormous debt to pay the coyote for facilitating her border crossing, so she was forced to remain and work until she had paid that debt.

At first, she tried to get a job at a small vegetable market, but the owner refused since she did not have a social security number. She became desperate for a job, and so she decided to clean houses in San Antonio. The work was hard - she did not get breaks, and it was physically intense - but she continued because she had no other options.

When Laura's father called her with an opportunity for her to come to Central Florida, she accepted. In Florida, she recommenced her search for work, specifically in plant nurseries, but she could not find anything. She finally found a job as a waitress in a Mexican restaurant, which she described as demeaning and embarrassing. She was constantly harassed 
by her boss and co-workers. Laura was sexually assaulted at this restaurant. After the assault, Laura did not return to the restaurant but instead tried to find a job at one of the many plant nurseries in the area, yet again had no success. She returned to the Mexican restaurant out of desperation.

Laura was finally able to leave the restaurant through marriage. She met her husband at the restaurant and, after they got married and she became pregnant, she quit her job. Now, she stays at home while her husband works as a cook in an Italian restaurant. She takes care of their two children and does the cooking, cleaning, and other forms of domestic work in their household. She also volunteers at Hope CommUnity Center in her free time.

\section{Isabella's story}

Isabella and her husband never meant to permanently immigrate to the U.S., but had planned to work in the U.S. for one year only because she had heard that the wages were better. They wanted to save enough money to return home to Mexico and build a house for their family. This plan was subverted, though, by the surprisingly high cost of living that they encountered upon arriving in the United States.

When she first arrived, Isabella worked at her brother-in-law's door factory during the night shift, but after her grandmother died, she shifted to working at a plant nursery. She left this job for a seemingly better job at a trash and recycling company, yet this job was very difficult for her and she disliked the work. She cleaned hotels next but could not work enough hours to make a living, so she returned to the plant nursery. Despite switching jobs so many times, she could not find a position that allowed her to fulfill her original goal and save enough money - she explained her highest immediate cost was her need to purchase a car to get to work. Rent was higher than she had anticipated as well. As Isabella continued to work at the plant nursery, she became aware of the potential dangers of working with the pesticides and chemicals she handled for her job. When she found that she was pregnant, Isabella quit her job because she was worried about the effects of those chemicals on her unborn child.

When her daughter was born, there was something wrong with her skull. Isabella's daughter had to get surgery when she was only four months old, and then had to wear a helmet for the subsequent eight months. The surgery was difficult for Isabella and her husband. Isabella was forced to remain unemployed in order to care for her daughter, but she needed more financial income because she could not get health insurance without legal status and the cost of her daughter's treatment and care was extremely high. Also, during this time Isabella and her husband divorced and Isabella became the sole caretaker for her daughter. Finally, Isabella found a part-time receptionist position at a Central Florida nonprofit organization. This job paid her a living wage, and after two years, she became a fulltime staff member. Isabella felt comfortable and empowered with her employment as a receptionist, yet she still missed Mexico and her family home.

\section{Yelena's story}

Yelena was a child, as was her younger sister, when her parents emigrated from Panama to the United States. She grew up undocumented and worked at a fast food chain restaurant because the hiring manager did not ask for her social security number. She also attended the University of Central Florida and studied nursing. She drove to work and school because she had no other time-efficient options, and each day that she did, she felt afraid. If she were pulled over, she would not be able to provide a driver's license. After a while, her father found someone to give her a fake driver's license, but the county from which she got the license somehow found out and put a warrant out for her arrest. ICE agents went to her home and aggressively questioned her father. "He didn't know his rights," Yelena explained, and so he told the agents where she worked.

The ICE agents arrested her publicly at her job and brought her to a detention center. They demanded that she tell them how she arrived in the U.S. and where her immigration documents were, but she did not remember - she had been only three years old when her family migrated. She was put in a room with white cement walls, no windows, and one other cellmate who was a young Mexican woman who did not understand English. As soon as her family found out, they hired both an 
immigration and a criminal attorney. The process cost her family thousands of dollars, but she was acquitted of the felonies by applying for DACA. DACA stands for "Deferred Action for Childhood Arrivals," and is an executive order under the Obama administration that allowed certain young undocumented immigrants to apply for temporary legalization. With DACA, she was free from the trauma of the detention center and from the fear of driving because she could now get a license. She was able to get a job with her nursing degree. "DACA gives you power," she told me, "because now you can survive. You can work and feed yourself good food. You have choice and freedom in what you want to do. You have a way to do something with your life, legally. Before, I didn't feel like a person."

Through analyzing these four women's stories, it is evident that their lives are fundamentally shaped by gender, their migration status, and their Latinx identities. Celia, Laura, Isabella and Yelena faced immense barriers to accessing safe work with a livable wage, and often their attempts to find such work were heavily shaped by gendered interactions, racism, and their undocumented statuses. Although each woman showed agency in obtaining work despite these oppressive structures, only Yelena and Isabella were able to find work that they felt was meaningful, safe, and had a sufficient wage. For Yelena, her life changed when she obtained legal status. In Isabella's case, she was able to obtain work with an activist organization devoted to advocating for migrants' rights. Without legal status and/or connections to such organizations, the other women were ultimately unable to escape oppressive structures.

Celia's story demonstrates the power of the oppressive forces faced by Latina migrant women in the United States. Gender shaped her experience in several ways, beginning from the fact that the network available to her was predominantly male. She migrated because her uncle decided that she must, and once in the United States, her only available living situations were with male family members. Although she demonstrated some agency through her decisions to move from her first uncle to the second and then back again, while she lived with these men she was subject to their rules and expectations. Furthermore, she was undocumented, so atop the stresses of living with strict and even abusive men, the only jobs she could access were in cleaning and cooking; because of the low pay of this work, she had to work both day and night. She finally found work that she liked when she waitressed at a Mexican restaurant, yet this lasted for only a year because her husband forced her to stop working. Celia's story reveals the vastness and complexity of structural oppression related to her gender, undocumented migration status, and Latinx identity.

Laura's experiences reflect very clearly how her intersectional identity in the U.S. led to a sharp contrast with her position in Mexico. There, she worked a semi-professional job as an assistant accountant, and her experiences with traditional women's work occurred predominantly after she crossed the border into the United States. She was dependent upon her father, a man, to help her get to Florida from her low-paying job in California, where she was not treated well. Her reason for migrating to the United States was to obtain work with better wages and conditions, yet she was even more limited in the United States than in Mexico. Her options for work were so limited that she chose to remain employed at the restaurant where she faced severe genderbased violence in the form of sexual assault. "There was no money in Mexico," she explained, "but it felt better there, even though the U.S. is supposed to be better."

Unlike both Celia and Laura, Isabella did escape the limitations for the types of work available to most undocumented Latina migrants in the United States. She did so despite being a single mother and dealing with her daughter's health issues, which were potentially related to Isabella's plant nursery work and exposure to dangerous pesticides and chemicals. Isabella worked at the plant nursery in the first place because it was the only job available to her that at least allowed for her daily survival, despite the fact that it still was not enough to save up and return to Mexico as she had originally hoped. These restrictions on job availability were a result of her gender and her undocumented status, which are also 
related to her Latinx identity. Isabella finally found a job outside of these restrictions when she obtained a part-time position as a receptionist. Because of the nature of the organization at which she worked, her undocumented status did not prevent her from obtaining the job. Furthermore, because the organization is based in activism and advocacy for the rights of workers regardless of gender, migration status, or national/racial/ethnic/ cultural identity, Isabella's work is not only a method of sustaining her family in the U.S., but also a form of resisting and subverting oppressive structures.

Yelena also escaped the labor limitations otherwise experienced by Latina migrant women. In contrast to Isabella, though, Yelena's ability to access a better job occurred as a direct result of obtaining legal status, demonstrating the importance of this identity factor. Before having legal status, she did not have access to work outside of her low-paying job at the fast food chain restaurant even though she had completed a nursing degree. Yet with DACA, Yelena was able to work in her field of study, which offered higher pay, benefits, and importantly, fulfilled her personal goal of becoming a nurse. Yelena associated her ability to work as a nurse with power, independence, and a way to integrate into American society far more fully than was possible before she obtained a legal status. Yelena's story demonstrates that being undocumented is an essential aspect of Latina migrants' oppression, and thus it is of tantamount importance to address the structural factors which make it more difficult for specifically female immigrants from Mexico, Central and South America to obtain legal status (Salcido and Menjívar 2013, 339).

As demonstrated in Laura and Celia's stories, many Latina migrants remain undocumented and thus face immense barriers to making a sustainable living in the United States. As well as limitations to types of work, I found that other consequences of the intersectionality of these women's identity factors included limiting their access to education and healthcare. In the following sections, I describe how Latina migrants' access to healthcare and education was also structurally limited due to gendered oppression, restrictions related to migration status, and how this connects to Latinx identity.

\section{Healthcare}

Through my research, I found that undocumented Latina migrants' access to healthcare was directly affected by the limitations related to the intersectionality of being Latinx, women, and undocumented in the United States. Access to healthcare was interwoven with access to other institutions, particularly to types of employment opportunities. Yet despite these immense barriers to women accessing healthcare, I found that many women showed agency by identifying other ways to access affordable healthcare.

My interviewees often experienced increased health risk factors due to the nature of their work. This problem was deepened by experiences of fear related to their identities as undocumented migrants and as women. In Isabella's case, a job in agricultural work led to increased risk of contact with dangerous chemicals and pesticides. Her daughter was born with skull complications likely related to Isabella's direct contact with chemicals and pesticides at the plant nursery. When she needed to travel to the hospital often to see specialists for her daughter, she would try to secure transportation but often had to drive herself. She was afraid each time that she would be pulled over and found to have no driver's license, leading to further financial difficulty and potentially deportation or other immigration proceedings. In fact, many of my interviewees noted stress, often related to negative work environments, driving without a license, and news of deportations and changes in immigration policy. This is consistent with findings by other researchers and is a crucial aspect of the intersectional oppression faced by many undocumented migrant women in the U.S. (Seelye 2017; Novak, Geronimus, and Martinez-Cardoso 2017; Lopez et al. 2017, 4).

In addition to these increased risks to their health, my interviewees faced significantly higher costs of healthcare since they could not access insurance due to their undocumented status. Furthermore, because their household incomes were generally limited due to the types of work available to them, this increased the 
difficulties they faced in paying for healthcare. Even when able to access healthcare, some women faced prejudice in the clinics they utilized. Patricia, who migrated to Central Florida from Mexico, said in an interview that she faced harassment and racism at one clinic. She witnessed some doctors and staff members refuse service to patients who they thought were undocumented based on their race or ethnicity. Patricia did not have any options other than this clinic, though; despite its threatening environment, it was the only one accessible to her and affordable with her lack of insurance.

Despite all of the barriers I have thus far outlined, many of my interviewees were still able to access healthcare. They did so through connecting with each other and finding out which clinics were the most trustworthy and affordable in the area. Some of my interviewees had to switch between doctors and medical centers multiple times in order to find healthcare accessible to them, which included the concerns of cost, Spanish language availability, proximity, and inter-personal communications with staff. Through obtaining healthcare despite the significant barriers faced due to oppressive structures related to the intersectionality of Latinx identity, gender, and the undocumented status, the women I interviewed demonstrated resilience on an individual and community level.

\section{Education}

Education played an important part in shaping how the women I interviewed were able to navigate life in the United States. It affected my interviewees' access to healthcare and employment, as well as representing a barrier to integration into American society. During my interviews, it became evident that levels of education were fundamentally shaped by gender norms in women's home contexts - yet women were also unable to access education in the United States.

For the women I interviewed, their experiences with employment fundamentally shaped their lives, especially since the types of work available to them were mainly informal and required heavy time commitments to make a living wage. As I explained above, two women, Isabella and Yelena, were able to access better jobs than the other women. Isabella obtained her position with the non-profit organization by connecting with the organization and working as a receptionist. I assert that she was able to break through the structural oppression otherwise limiting undocumented Latina women because of the immigrant rightsoriented nature of the organization. Yelena was able to become a nurse and, when we spoke, was taking courses toward a medical degree to become a doctor. Yelena's success in her career was a direct product of her ability to access education in combination with the legalization of her migration status through DACA. To describe the structural forces barring the other women I interviewed from the same opportunities, I will compare Yelena's experiences to the other women's and explain the impact of this difference.

Yelena's ability to obtain a college degree was a consequence of multiple factors. First, she was only a child when her family migrated to the U.S. from Panama. She grew up in Central Florida, and quickly learned to speak English. She attended college at the University of Central Florida because of her language skills and because of her ability to complete high school, which many other women I interviewed had been unable to do in their home countries. When Yelena first graduated with her college degree she was still unable to work due to her undocumented status, but when she successfully applied for DACA she was able to get a professional nursing position.

The other women I interviewed were adults when they immigrated to the U.S. and most spoke limited English. English literacy is an important factor in accessing education in the United States, which is notably ironic since English literacy is also a skill gained from accessing education in the United States. Furthermore, other migrant women I interviewed were unable to study in the U.S. because they needed to spend their time working in order to support their families. Offemployment time was filled with gendered tasks centered around household work and childcare. Yelena's situation was different because she was not responsible for any children nor her household, and thus she was free to study at university. Finally, Yelena's 
migration status change upon her reception of DACA allowed her to be hired to work as a professional nurse, which fundamentally changed her life in the United States. She stated that it gave her "power" and "freedom of choice." This is a major difference between Yelena's situation and that of the other migrant women I interviewed, as exemplified in one statement by Rosalita, another of my interviewees. She told me that the biggest hindrance faced by undocumented Latina women is their inability to get an education. She lamented that American women (who are citizens) do not understand how privileged we are to study in colleges and universities, because we are then able to get jobs that not only pay well, but that we actually enjoy. Rosalita directly related the ability to achieve education with self-confidence and respect within society. This comparison demonstrates the complex nature of the barriers faced by my interviewees in accessing education and employment.

Despite these immense barriers, many of my interviewees spoke of ways in which they demonstrated agency and discovered unique ways to access education for themselves or their families. Celia wanted to teach her daughter, Raquel, the meaning of education because Celia wanted her daughter to have as many opportunities as possible. Celia explained that in order for this to happen, Raquel would have to learn how to work hard for her own education. Tatiana echoed Celia's words, explaining that she left Mexico so that her children would have access to education. In Mexico, she explained, school costs too much because parents must also pay for lunches during the school day, as well as for their children's uniforms. Patricia also said that despite missing her life in Mexico, she chose to remain in the U.S. to provide her children with a good education and thus better career options. Throughout my interviews, this theme arose: my interviewees deeply felt the importance of education and sometimes even weighed its importance against their own happiness. They realized that their own lives would be better if they obtained an education, yet they also understood the barriers they faced to obtaining higher education. The women I interviewed resisted oppression by ensuring that their children would have access to education, and thus better opportunities in their lives, even if my interviewees themselves would not.

Women also resisted the oppressive structures barring them from education by accessing courses offered at Hope CommUnity Center and other organizations in Central Florida, including English language courses, classes in parenting, high school diploma courses, and more. Laura and Elisa specifically discussed engaging in these courses as a way to empower themselves as mothers and women. Laura told me that she attended an English language course and parenting course at Hope CommUnity Center to be an advocate for her children as they grow up in the United States. She explained that these courses gave her courage, as well as the ability to help other migrant women in her community. Elisa, who spoke English extremely well during our interview, explained that she learned English through taking courses at Rose Literacyii and Hope CommUnity Center. She also obtained her GED after studying through these courses. Her motivation was to be able to speak with her son's teachers and be more involved in his life as he interacts with American institutions and society. Through obtaining education despite structural barriers, my interviewees demonstrated their agency and found power in motherhood and a community of women.

\section{Community Organizations and Resistance}

In my analysis of undocumented Latina migrants' access to work, healthcare, and education, I found that women faced immense structural barriers; however, they also subverted their oppression through finding unique ways to fulfill their needs and build lives in Central Florida. I found that many of my interviewees created ways to negotiate oppressive systems by connecting with organizations in Central Florida that provided services for undocumented immigrants - the most often mentioned of these organizations were Hope CommUnity Center and the Farmworker Association of Florida.

Previous research indicates that such organizations are indeed an important mechanism for addressing the needs of oppressed migrant populations and are often able to facilitate integration (Blackwell 2015, 
146). Hope CommUnity Center works toward these goals through its citizenship workshops, English language classes, GED courses, parenting classes, and community-building events. Hope CommUnity Center also provides a means of collective empowerment for migrant women like Laura and Elisa. Other ethnographers who have worked with immigrant-rights organizations in other contexts have also attested to their success in immigrant communities. Scholar and activist Maylei Blackwell $(2015,146)$ states that such organizations have the power to "reduce institutional, cultural, linguistic, and economic barriers" for migrant women. Migrant women use these kinds of NGOs to build their social networks and empower each other; previous research has documented how migrant women also utilize these organizations to build power for their own activist movements (Hernandez 2017). I observed this occurring at Hope CommUnity Center, where there is a powerful group of immigrants and allies who campaign for immigrant rights in Washington, D.C. as well as conducting community events and campaigns in Central Florida. My own observations revealed that organizations such as Hope CommUnity Center and FWAF are immensely powerful tools for immigrants, and specifically migrant women, to resist the structures of their oppression.

\section{Conclusion}

My research was limited by my positionality as a white American citizen. As such, I have not experienced personally what it is to be undocumented in the U.S. or Latinx. My research project developed through personal interest in immigrant rights and connections with Hope CommUnity Center and the Farmworker Association of Florida. In addition, I am not fluent in Spanish, and this was a limiting factor because I worked with translators during interviews and so there could have been information lost during the interview process. Furthermore, my research was limited because my formal interview process occurred over the span of only one year. I would recommend that future research take more time and engage with more interviewees and organizations in the area. Finally, although I believe that the theoretical framework of intersectionality provided me with the ability to address power structures related to identity factors, it potentially limited my analysis by emphasizing identity over "structures of inequality" (Cho, Crenshaw, and McCall 2013, 797). Using an identity-based approach demonstrated more about projections of identity upon my interviewees, rather than their own conceptions of their identities, which are far more complex and dynamic. That said, analyzing the research material using etic or ascribed categories of identity helped pinpoint the structural ways in which they lead to the women's vulnerability, since the power structures that affect them are organized along etic, or 'outsider', categories.

Undocumented Latina migrants face systemic oppression in the United States due to the intersectionality of their identities as women, undocumented, and Latinx. Systems of exclusion prevent these women from accessing safe, fair and meaningful employment, affordable healthcare, and education services. Despite this, my research shows that some undocumented migrant women are able to resist the multi-dimensional oppression they face when they try to access healthcare, education and employment. I found that women utilized community organizations as a mode of activism and community organizing. Notably, though, being undocumented is the most oppressive factor I found during interviews that blocked women from their rights. The undocumented status itself is an intersectional issue because of American policies which make it more difficult for migrants from Mexico, Central America, or South America, and specifically for women from these areas, to legalize their status. American immigration policy must address these fundamental failures by creating opportunities for undocumented migrants to legalize their status, with specific attention toward gendered issues in immigration policy. As Kimberlé Crenshaw (1991) wrote, intersectional systems of oppression cannot be understood in terms of one identity factor or another, but must be examined as the relationship between diverse structures which are not independent of each other. My research illustrates the intersectional relationship between gender, undocumented status, and Latinx identity that are linked to systemic oppression in the United States. In 
response, I call for immigration policies which address this oppression and create real pathways for undocumented Latina migrants to gain legal status. My research also demonstrates the resilience and power of migrant women and the diversity of experiences they have regardless of the structural vulnerabilities they face in the United States. 


\section{Acknowledgements}

Thank you from the bottom of my heart to the women with whom I spent time with for this research project. You trusted me with your time and your stories, and that is endlessly meaningful. Thank you as well to Dr. Rachel Newcomb, who helped me become a better student of anthropology and overall person through learning from her example. Thank you to Dr. Nolan Kline, who advised the writing of this thesis and shared with me his passion for applied anthropology. Finally, thank you to the organizations in Central Florida which constantly inspire me with their power and love.

\section{Endnotes}

'Yelena was able to work as a nurse only after she applied for, and received, DACA and was therefore given a social security number.

iiThis organization no longer operates in Central Florida, but from what I gathered in our interview, it was a nonprofit which offered free English language courses for immigrants in the community. 


\section{References}

Armenta, Amada. 2017. Protect, Serve, and Deport: The Rise of Policing as Immigration Enforcement. Berkeley, CA: University of California Press.

Blackwell, Maylei. 2015. "Geographies of Difference: Transborder Organizing and Indigenous Women's Activism." Social Justice 42(3 $-4): 137-154$.

Cherubini, Daniela. 2011. "Intersectionality and the study of lived citizenship: a case study on migrant women's experiences in Andalusia." Graduate Journal of Social Science, 8(2):114-136.

Cho, Sumi, Kimberlé Williams Crenshaw, and Leslie McCall. 2013. "Toward a Field of Intersectionality Studies: Theory, Applications, and Praxis." Signs 38(4):785-810.

Coleman, Mat. 2008. "Power and space in the colonial present." Political Geography 27:339-370.

Crenshaw, Kimberlé. 1991. "Mapping the Margins: Intersectionality, Identity Politics, and Violence against Women of Color." Stanford Law Review 43(6):1241-1299.

De León, Jason. 2015. The Land of Open Graves: Living and Dying on the Migrant Train. Berkeley, CA: University of California Press.

Fernández, Lilia. 2010. “Review: Deconstructing Immigrant Discourse." Journal of American Ethnic History 30(1):107.

García, San Juanita. 2017. “Racializing “illegality”: An intersectional approach to understanding how Mexican-origin women navigate an anti-immigrant climate." Sociology of Race and Ethnicity, 3 (4):474-490.

Goldring, Luin. 2001. "The Gender and Geography of Citizenship in Mexico-U.S. Transnational Spaces." Identities Global Studies in Culture and Power 7(4):501-537.

Hernández, Raúl Diego Rivera. 2017. “Making Absence Visible: The Caravan of Central American Mothers in Search of Disappeared Migrants." Latin American Perspectives 44(5):108-126.

Herrera, Giocanda. 2013. "Gender and International Migration: Contributions and Cross-Fertilizations." Annual Review of Sociology 39:471-489. 
Hondagneu-Sotelo, Pierrette. 1992. “Overcoming Patriarchal Constraints: The Reconstruction of Gender Relations Among Mexican Immigrant Women and Men." Gender \& Society 6(3):393415.

Horton, Sarah B. 2016. "Ghost Workers: The Implications of Governing Immigration Through Crime for Migrant Workplaces." Anthropology of Work Review 37(1):11-23.

Kynsilehto, Anitta. 2011. "Negotiating intersectionality in highly educated migrant Maghrebi women's life stories." Environment and Planning $A$, 43(7):1547-1561.

Kline, Nolan. 2017. "Pathogenic Policy: Immigrant Policing, Fear, and Parallel Medical Systems in the US South." Medical Anthropology 36(4):396-410.

Lopez, William D., Daniel J. Kruger, Jorge Delva, Mikel Llanes, Charo Ledón, Adreanne Waller, Melanie Harner, Ramiro Martinez, Laura Sanders, Margaret Harner, and Barbara Israel. 2016. “Health Implications of an Immigration Raid: Findings from a Latino Community in the Midwestern United States." Journal of Immigrant Minority Health 19(3):702-708.

Neumann, Inga D., Alexa H. Veenema, and Daniela I. Beiderbeck. 2010. "Aggression and Anxiety: Social Context and Neurobiological Links." Frontiers in Behavioral Neuroscience 4 (12): www.ncbi.nlm.nih.gov/pmc/articles/PMC2854527/.

Novak, Nicole L., Arline T. Geronimus, and Aresha M. MartinezCardoso. 2018. "Change in birth outcomes among infants born to Latina mothers after a major immigration raid." International Journal of Epidemiology 46(3):839-849.

Salcido, Olivia, and Cecilia Menjívar. 2012. "Gendered Paths to Legal Citizenship: The Case of Latin-American Immigrants in Phoenix, Arizona." Law \& Society Review 46(2):335-368.

Seelye, Katharine Q., and Jess Bidgood. 2017. “'Don't Open the Door': How Fear of an Immigration Raid Gripped a City." New York Times, April 6, 2017. https://www.nytimes.com/2017/04/06/us/ immigration-raid-fear-brockton-massachusetts.html.

Silvey, Rachel. 2006. "Geographies of Gender and Migration: Spatializing Social Difference." The International Migration Review 40(1):64-81. 
Willen, Sarah S., Jessica Mulligan, and Heide Castañeda. 2011. “Take a Stand Commentary: How Can Medical Anthropologists Contribute to Contemporary Conversations on 'Illegal' Im/migration and Health?" Medical Anthropology Quarterly 25(3):331-356.

Zavella, Patricia. 2016. “Contesting Structural Vulnerability through Reproductive Justice Activism with Latina Immigrants in California." North American Dialogue 19(1):36-45.

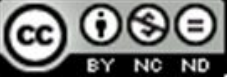

This work is licensed under a Creative Commons

Attribution-NonCommercialNoDerivatives

4.0 International License. 